\section{Learning and usefulness stemming from collaboration in a maritime crisis management exercise in Northern Norway}

Maritime crisis management exercise

\author{
Leif Inge Magnussen, Eric Carlstrøm, Jarle Løwe Sørensen and \\ Glenn-Egil Torgersen \\ University College of Southeast Norway, Kongsberg, Norway \\ Erlend Fritjof Hagenes \\ Department of Health, Nord Universitet, Bodø, Norway, and \\ Elsa Kristiansen \\ School of Business, University College of Southeast Norway, Kongsberg, Norway
}

Received 26 June 2017 Revised 11 October 2017 17 October 2017 18 October 2017 18 October 2017 20 October 2017 Accepted 20 October 2017

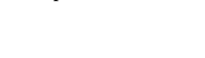

\begin{abstract}
Purpose - This research investigates the perceived collaboration between public, private, and volunteer organisations during maritime crisis work, with an emphasis on learning and collaboration. The purpose of this paper is to investigate participants' perceived collaboration training in relation to learning and usefulness.

Design/methodology/approach - The exercise studied in this research was run in the far North in Norway. It was estimated by the participants to be Europe's most extensive exercise in 2016. Mixed methods research approach was applied, i.e. on-site observations, photos and interviews were conducted during the exercise. After the exercise, an online survey was distributed to emergency personnel holding different positions in conjunction with this exercise.

Findings - As reported, the exercise contributed to new insights on the relationship between collaboration and learning. The study showed that collaborative elements in exercises contribute to perceived learning $\left(R=0.86, R^{2}=0.74\right)$, and that learning in turn had a perceived beneficial effect on actual emergency work $\left(R=0.79, R^{2}=0.62\right)$.

Research limitations/implications - The possible research implications from this study include more focus on collaboration and new training schemes that could increase learning and usefulness.

Practical implications - Collaboration between actors seemed to suffer from the size of the exercise. A smaller exercise, less dependency on predetermined scripts, and more receptivity towards improvisation could improve collaboration.

Social implications - Increased awareness on the outcomes of collaboration exercise might increase their learning and usefulness, providing societies with improved rescue services.

Originality/value - This research implies that increased perceived collaboration has an effect on learning and usefulness in maritime exercises.
\end{abstract}

Keywords Exercise, Learning, Collaboration, Norway, Disaster training

Paper type Research paper

\section{Introduction}

Collaboration exercises that handle crisis are arranged in order to improve inter-organisational integration (Kim, 2013). However, in the few studies that have been performed on such exercises, it has proven to be difficult to create cross-boundary

(C) Leif Inge Magnussen, Eric Carlstrøm, Jarle Løwe Sørensen, Glenn-Egil Torgersen, Erlend Fritjof Hagenes and Elsa Kristiansen. Published by Emerald Publishing Limited. This article is published under the Creative Commons Attribution (CC BY 4.0) licence. Anyone may reproduce, distribute, translate and create derivative works of this article (for both commercial \& non-commercial purposes), subject to full attribution to the original publication and authors. The full terms of this licence may be seen at http://creativecommons. org/licences/by/4.0/legalcode 
$\mathrm{DPM}$

27,1

130

collaboration (Berlin and Carlström, 2008 pp. 182,183). Organisations that are supposed to collaborate have proven to be satisfied working side-by-side rather than synchronously or across boundaries (Van Wart and Kapucu, 2011, pp. 504-507; Andersson et al., 2014, pp. 87-88). Such results have contributed to doubting the value of collaboration exercises. The outcomes in terms of learning and usefulness have been questioned (Berlin and Carlström, 2015b, p. 454). Norway is of special interest when studying crisis collaboration. In contrast to other Scandinavian countries, Norway has legislated collaboration in its emergency preparedness regulations (Regjeringen, 2017). The collaboration principle states that authorities, enterprises, and agencies have an independent responsibility to ensure collaboration related to crisis management. The legislation was a response to an evaluation on the terrorist attacks in Oslo and Utøya on 22 July 2011 (Gjørv, 2012). One severe critique from the evaluation was that even if there was an established system of command and control within each participating organisation, misunderstandings and lack of collaboration delayed the operation.

Data in this research are stemming from "Exercise NORD 2016", which was a full scale collaboration exercise hosted by Nord University in Bodø, Norway during "Emergency preparedness Week" in April 2016. Emergency preparedness was the topic of the municipality organisation, and they have this as an annual enterprise. Exercise Nord was run by a local university centre, while the Search and Rescue (SAR) operations were coordinated from the national Joint Rescue Coordination Centre of Northern Norway located in the city of Bodø. The Norwegian SAR Services work is integrated which means that the same rescue coordination centre coordinates land, sea, and air rescue operations. This is considered cost-effective, practical, and easy to run and manage (Joint Rescue Coordination Centers, 2017). The national rescue services are often carried out through mobilisation and collaboration between emergency organisations.

The purpose of this study was to investigate perceived collaboration between responding organisations during maritime crisis work, with an emphasis on the possible effects on learning and usefulness.

\section{Literature review}

In a Swedish study, Berlin and Carlström (2015b) have shown that collaborative elements in exercises contribute to perceived learning $\left(R^{2}=0.53\right)$, and learning in turn has a perceived beneficial effect on actual crisis work $\left(R^{2}=0.26\right)$. However, according to the participants in the Swedish study, the exercises were characterised by long waiting times and gave few opportunities to practise different strategies in collaborations between different agencies. The participants thought that the exercises were more useful to command officers than operational staff. The study indicated that by strengthening the collaborative elements of the exercises, learning could be improved. A Dutch study by Scholtens et al. has been critical to classical command and control models that obstruct decentralised and fast decision making. Such systems favour single organisational commands before multidisciplinary coordination. The authors underlined that the way in which exercises were conducted is a repetition of already known skills and not necessary interaction among teams.

\subsection{Collaboration in an organisational perspective}

In a study of traditional collaboration exercises (Berlin and Carlström, 2015a), the collaborative elements did contribute to perceived learning and according to the participants, the exercises were characterised by long waiting times and gave few opportunities to practice different strategies. Only a few felt that they had learned something about the collaborating organisations' ways of communicating and prioritising. Many also thought that the exercises were more useful for command officers than for operational personnel. The study indicated that by strengthening the collaborative elements 
of the exercises, the actual emergency work could be developed. Furthermore, crisis organisations tend to lack understanding of the meaning of each other's culture, roles, concepts, symbols and routines (Berlin and Carlström, 2013; Martinussen, 2013). In contrast to others, crisis organisations make decisions under extreme time pressure and are forced to perform operations based on a minimum of information. Lack of time to process information underpins steep hierarchies as well as an effective command and control. Previous research of crisis organisations has shown that workload transitions negatively affect performance (Prytz et al., 2015, p. 237). On the other hand, Bjørnstad (2011) studied flexibility, effectiveness and alignment from survey data based on NATO force exercises. She found that flat structures and decentralised processes contributed to organisational effectiveness and flexibility. Carlson (2014) interviewed exercise participants from fire, law enforcement, public health and emergency management after multi-agency disaster response exercises, in order to analyse inter-organisational discussions. She found that the discussions helped collaborators to generate productive conflict resolutions and ultimately achieve effective inter-organisational collaboration. The idea was for organisations to practise the ability to enlist the help of each other prestique-free, as well as the ability to switch between different collaboration strategies as the situation required (Nemeth et al., 2011).

In some situations collaboration might hinder the efficiency, especially when it conflicts with established routines or procedures. Over-adaptive participants are unable to make an optimal decision out of respect for organisational charts, legislation, or senior officers. What is required is a sensitive and reflective collaboration that can interpret a situation and act accordingly (Dreyfus and Dreyfus, 1986). Collaboration is a horizontal process that is characterised by a joint cross-sector focus on goal achievement through the uniting of resources (Murphy et al., 2015) and the sharing of risk (Andersson et al., 2014). As focussing on collaboration is more useful and internally advantageous than individual initiative taking, it should be applied as a problem-solving and vision-sharing instrument (Jamal and Getz, 1995). Collaboration theories are based on an empirical phenomenon that focusses on empirical data verification (Kang, 2014). Hence, they should be considered as middle-range theories (Merton, 1949) rather than grand theories (Mills, 1959). John Stuart Mill and John Locke are two theorists that have contributed to collaboration theories and perspectives through their focus on rewards and social gain, where the focus on collaboration could be viewed in support of achieving a greater good compared to a quest for selfish gain (Berlin and Carlström, 2008). Cross-sector crisis collaboration relates on both vertical and horizontal perspectives, as well as formal or informal agreements (Martinussen, 2013). Vertical collaboration has a bottom-up focus where there is a prominent focus on coordination, control, and power. The antithesis is horizontal collaboration, described more as an ideal perspective where the distribution of power and sharing of available resources is based on utility value and general agreements (Martinussen, 2013). Both vertical and horizontal collaboration can be based on normal and informal agreements. Hence, formal agreements are the outcome of a structure and a desire for risk reduction, while informal agreements rest on casually developed relationships and routines (Berlin and Carlstrøm, 2009; Kristiansen et al., 2017).

In crisis work, there are multiple ways that stakeholders may choose to engage in collaboration. The simplest form is sequential collaboration that is comparable to an industry-based assembly line approach (Axelsson and Bihari-Axelsson, 2006) where the involved actors perform their tasks individually before handing them over to the next player. An alternative to sequential collaboration is parallel collaboration (Berlin and Carlström, 2011). Here, the interested stakeholder organisations and actors work next to each other, but they seldom cross organisational boundaries or assist cross-sectors. An ideal form of collaborative crisis work is a synchronous collaboration (Berlin and Carlström, 2011). This is when the stakeholders share their resources and a common focus on flexibility and effectiveness without prestige and regardless of professional affiliation.
Maritime crisis management exercise 
$\mathrm{DPM}$

27,1

132

\subsection{Collaborative learning in crisis (CLC)}

CLC is about two major dimensions in a learning community. The first relates to a learning process during training or in a real situation that develops the individual's core competencies. The other dimension is the utilisation of the core capacities interactively and complimentarily during training or in a vivid real-life incident. This learning perspective has a concurrent nature and must be deliberate and organised. It must be included in training to develop interactional skills and it must be included in the strategic plans of the organisation. In light of collaboration (interaction), Steiro and Torgersen (2013) have defined the term concurrent learning as "A deliberate and continuously functional and interacting learning process among actors that occurs simultaneously with the interaction" (p. 335). CLC is just one premise for effectiveness in practice (Torgersen and Steiro, 2009; Torgersen, 2015). The empirically based model underlines the extent and quality of practical effectiveness. These outcomes are defined by the involved agencies' ability act and contributed to recovery from future crises.

\section{Methods}

The Exercise Nord 2016 that was investigated was based on multiple scenarios; all together, approximately 1,500 actors participated in this exercise. The exercise took place within an air traffic control zone in connection to the Bodø airport. The background for the exercise was a ship that had been to the coast of Greenland as a combined research and cultural expedition. Students, teaching staff, and a delegation from one military squadron were on-board. The ship was now returning to Bodø. Around 6 a.m., difficulties are reported on-board by the ship when approaching land; this turns out to be a fire when the ship approaches Bodø. The exercise took approximately eight hours (with briefing and debriefing), closely timed in a 4-hour schedule underpinning the exercise's perceived success. The structure of the event followed nine phases - a fire on-board a vessel at sea involving the local RITS team:

- in-sea evacuation from the vessel, involving both military and civilian rescue helicopters;

- on-land salvage and first aid involving Civil protection agencies;

- air and land based medical transportation and coordination;

- dangerous emissions from vessel;

- the stowaway, fleeing and protection (asylum) challenges involving the police department took place;

- the training of trauma room capacity and coordination testing involving the local hospital;

- reception and next of kin services; and

- an on-land fire alarm due to fuel leakage from SAR helicopter.

This was followed by a "Hot Wash Up" or immediate evaluation one hour after the final phase, where different agency representatives summed up their "views" on the exercise. A final report is unknown to the researchers, but several intra-organisational evaluations where conducted.

\subsection{Data collection}

Four researchers observed the exercise and we used mixed methods survey questions consisting of both qualitative and quantitative questions. The procedures and instrument is described below. 


\subsection{Participants and procedure}

Before the exercise, ethical approval from the Norwegian Social Science Data Services (NSD 44815) was given. The research is in compliance with the ethics concerning collection and storage of data made by NSD. In addition to the interviews and observations, the data were generated from an internet-based survey (QuestBack) and sent to the participants that we had access to from the e-mail list in the script (i.e. the basic manuscript of all aspects of the exercise; $N=65$ ). Hence, the focus here is on the experiences of the major maritime stakeholder teams (e.g. the crew on-board in the included vessels and helicopter squadrons).

Three reminders were sent out the following weeks $(N=53)$, and we had an 82 per cent response rate from those participants who we were able to directly contact via e-mail. Some implications from this are that we have a representative from people trained and listed in the manuscript. An assumption is that this represents seniority rather than juniority within the investigated population. If this assumption is correct, there is less weight on "foot soldiers" involved in the exercise (i.e. medics, bosuns-men and ambulance workers). We had little control on who got the distributed link and why, if they received it, they did not answer. The data were collected inside one country.

\subsection{Instrument}

The instrument captured both quantitative and qualitative data, including, for example, the actors' experiences of the collaboration, learning and usefulness of the exercise. We used an existing survey instrument developed to measure collaboration, perceived learning, and utility (CLU instrument) from 1 (strongly disagree) to 5 (strongly agree) on a Likert scale (Berlin and Carlström, 2015a). The homogeneity of the items was analysed by calculating Cronbach's $\alpha$. The results showed a Cronbach's $\alpha$ of 0.88 . Statistical significance was established at $p<0.05$ and all tests were two-tailed (Altman, 1991). The analysis stems primarily from descriptive data and regressions (bivariate and multiple). Means and standard deviations were used for descriptive purposes. A total of 53 participants responded to the web-based survey.

\subsection{Analysis}

The results from the questionnaire were downloaded in an excel format. Before importing the data to SPSS 24, the open-ended questions were copied into a word file. The data sets contained 1 (strongly disagree) to 5 (strongly agree), and 9 (I don't know). The organising group also replied to the survey; they were excluded as discrete missing values before descriptive statics were run. In this analysis the results on every question in the survey were sorted by descending means. This was done in an effort to highlight and point out the extremes.

\section{Results}

The mean age of the participants was 47 years $(\mathrm{SD}=12.7)$. In all, 64 per cent were men. The youngest participant was 19 and the oldest was 65 years old. Most of the participants were employed by the county council or a municipality (44 per cent). The second most represented organisation was the coast guard (21 per cent). The rest of the participants were employed in civil defence organisations, the National Guard, ambulance services, the University Nord, and The Norwegian Society for Sea Rescue. The experiences of exercises varied among the participants. They had participated in zero to a maximum of 100 exercises $(M=13.8 ; \mathrm{SD}=25.8)$.

\subsection{Collaboration}

A majority of the participants (84 per cent) considered the exercises to be focussed on collaboration $(M=4.2, \mathrm{SD}=0.99)$, and 56 per cent thought there were sufficient forms of discussion in connection to the exercise $(M=3.44, \mathrm{SD}=1.3)$. As many as 72 per cent found their points of view being regarded $(M=3.93, \mathrm{SD}=1.16)$. Still, the majority of participants 
$\mathrm{DPM}$

27,1

134

(51.1 per cent) felt that collaborations started on time without unnecessary waiting time $(M=3.38, \mathrm{SD}=1.22)$, but as few as 44.4 per cent regarded the instructions of collaborative practices to be clear $(M=3.27, \mathrm{SD}=1.25)$. More than half of the participants ( 60.5 per cent) thought there were opportunities to improvise and try alternative strategies in collaboration with participating organisations $(M=3.47, \mathrm{SD}=1.28)$, but even if they tried alternative strategies, 85.4 per cent repeated well-known activities during the exercise $(M=4.46$, $\mathrm{SD}=1.07)$. As many as 84 per cent considered that personnel who needed to practise collaboration were engaged in the exercise $(M=4.38, \mathrm{SD}=0.9)$. The mean of all items within the collaboration dimension was $2.98(\mathrm{SD}=0.86$; Table I).

\subsection{Learning}

Most of the participants (82.4 per cent) answered that they learned something new during the exercises $(M=3.96, \mathrm{SD}=1.2)$, and a majority (61.5 per cent) considered themselves to have learned something new about the collaborating organisations $(M=3.67, \mathrm{SD}=1.2)$. A bit more than half of the participants learned something about communication patterns of the collaborating organisations ( 54 per cent; $M=3.58, \mathrm{SD}=1.18$ ) but less than a third (29.2 per cent) learned something about their concepts and abbreviations $(M=2.54, \mathrm{SD}=1.4)$. Less than half of the participants (43 per cent) perceived themselves as having learned something about prioritised activities among collaborating organisations $(M=3.27, \mathrm{SD}=1.04)$. The mean of all items within the learning dimension was $3.22(\mathrm{SD}=1.08$; Table $\mathrm{I})$.

\subsection{Usefulness}

The main portion of participants (60.8 per cent) considered the exercises to be useful during actual emergency work and real-life activities $(M=3.73, \mathrm{SD}=1.36)$; however, only 40 per cent of participants regarded the exercises as having an impact on their daily work $(M=3.04, \mathrm{SD}=1.3)$. This addresses the relevance of the training. The exercises were considered to be slightly more useful to the command officers (51.1 per cent; $M=3.4$, $\mathrm{SD}=1.05$ ) than to the ordinary police, fire, and ambulance personnel (48.6 per cent; $M=3.18, \mathrm{SD}=1.0)$. The mean of all items in the dimension of usefulness was 3.09 $(\mathrm{SD}=0.98$; Table I).

\subsection{Bivariate regressions}

The causal effects of the three dimensions (collaboration, learning, and usefulness) were tested in bivariate regressions. Collaboration was correlated to the mean learning score across the learning items. A significant correlation was found between the item "my points of view were regarded" and learning, explaining a significant proportion of variance in the mean learning score $\left(R=0.58, R^{2}=0.34, p<0.001\right)$. This was closely followed by "opportunities to improvise" $\left(R=0.51, R^{2}=0.26, p<0.001\right)$, "clear instructions of collaborative practice" $\left(R=0.46, R^{2}=0.21, p<0.001\right)$, and "the exercise focussed on collaboration" ( $\left.R=0.41, R^{2}=0.17, p<0.001\right)$. Both the items "discussions in connection to the exercise" ( $\left.R=0.39, R^{2}=0.15, p=0.02\right)$ and "collaboration was initiated immediately" $\left(R=0.36, R^{2}=0.06, p=0.09\right)$ showed a significant proportion of variance in the mean learning dimension but a somewhat weaker correlation. The items "staff in need of exercise

Table I.

Mean values (SD) for the 53 participants answering the CLU scale divided into subscales
Dimensions

Mean (SD)

Collaboration

Learning

Usefulness

All
$2.98(0.86)$

3.22 (1.08)

$3.09(0.98)$

$3.10(0.97)$ 
participated" $\left(R=0.24, R^{2}=0.06, p=0.09\right)$ and "well-known activities was repeated during the exercise" ( $\left.R=0.17, R^{2}=0.03, p=0.24\right)$ did not display any significant correlations (Table II). All the items in the learning dimension were significantly correlated to the mean usefulness score across the items associated with the usefulness measurements. This was true in the correlation between the item "learned new things" and usefulness $(R=0.63$, $R^{2}=0.40, F=32.41, p<0.001$ ) (Table IV).

A somewhat weaker but substantial correlation was found for the item "learned about communication patterns of the collaborating organisations" $\left(R=0.51, R^{2}=0.26, F=14.13\right.$, $p<0.001$ ), closely followed by "learned about organisational aspects of the collaborating organisations" $\left(R=0.50, R^{2}=0.25, p<0.001\right)$, and "learned about the way collaborating organisations prioritise activities" $\left(R=0.50, R^{2}=0.25, p=0.002\right)$. The item "learned new concepts and abbreviations used by collaborating organisations" $\left(R=0.14, R^{2}=0.02, p=0.006\right)$ was also significantly correlated but displayed a somewhat weaker correlation (Table III). 4.5 multiple regressions from the bivariate regressions, significant variables were selected and tested in two multiple regressions (Table IV). The collaborative characteristics did together predict 86 per cent $\left(R^{2}=0.74\right)$ of the variance in learning. This meant that 14 per cent of the predicted variance was unaccounted for. None of the variables were still significant in the regression even if "clear instructions of collaborative practise during the exercises" did display a significant proportion of variance close to $p<0.05$ ( $\operatorname{sig} 0.06$; Table V). In the second multiple regression, all the items of perceived learning did predict 79 per cent $(R 2=0.62)$ of the variance in usefulness. This meant that 21 per cent of the predicted variance was unaccounted for in the regression. One of the variables, "learned new things during the exercise", was still significant. Even if "learned new concepts and abbreviations during the exercise" was close to significant, the remaining four variables displayed moderate $T$-values and lacked significance on their own (Table V).

\begin{tabular}{lcrrrr}
\hline Collaborative characteristics of the exercise & Pearson's $R$ & $R^{2}$ & $F$-value & $T$-value & Sig. \\
\hline 1. The exercise focussed on collaboration & 0.41 & 0.17 & 9.65 & 3.11 & 0.00 \\
2. Discussions in connection to the exercise & 0.39 & 0.15 & 5.65 & 2.38 & 0.02 \\
3. Opportunities to improvise & 0.51 & 0.26 & 14.13 & 3.76 & 0.00 \\
4. Collaboration was initiated immediately & 0.36 & 0.13 & 6.90 & 2.63 & 0.01 \\
5. Well-known activities were repeated during the exercise & 0.17 & 0.03 & 1.43 & 1.20 & 0.24 \\
6. Staff in need of exercise participated & 0.24 & 0.06 & 2.10 & 1.73 & 0.09 \\
7. Clear instructions of collaborative practice & 0.46 & 0.21 & 11.46 & 3.39 & 0.00 \\
8. My points of view were regarded & 0.58 & 0.34 & 20.90 & 4.57 & 0.00
\end{tabular}

Note: Independent variables: collaborative characteristics of the exercise, dependent variable: learning (sig. $=p<0.05, n=53$ )
Maritime crisis management exercise

135
Table II.

Bivariate regression of items in the collaborative dimension of learning
Pearson's $R \quad R^{2} \quad F$-value $T$-value $\operatorname{Sig}$.

1. Learned new thing during the exercise

2. Learned about organisational aspects of the collaborating organisations

3. Learned about communication patterns of the collaborating organisations

4. Learned about the way collaborating organisations prioritise activities

5. Learned new concepts and abbreviations used by the collaborating organisations

$\begin{array}{lllll}0.63 & 0.40 & 32.41 & 5.69 & 0.00 \\ 0.50 & 0.25 & 16.23 & 4.03 & 0.00 \\ 0.51 & 0.26 & 14.13 & 3.76 & 0.00 \\ 0.50 & 0.25 & 15.66 & 3.96 & 0.00 \\ 0.45 & 0.20 & 11.69 & 3.42 & 0.00\end{array}$

Note: Independent variables: learning, dependent variable: usefulness (sig. $=p<0.05, n=53$ )
Table III.

Bivariate regression of items in the learning dimension of usefulness 
$\mathrm{DPM}$

27,1

136

Table IV.

Multiple regression

of items in the

collaboration

dimension of learning

\section{Discussion}

The purpose of this study was to investigate the perceived collaboration between responding organisations during maritime crisis work, with an emphasis on the possible effects on learning and usefulness. The results indicated that the studied exercises focussed on collaboration, contributed to perceived learning and contributed to usefulness. Within the collaboration dimension, a majority of participants found their points of view being taken into account. These results indicated an open and collaborative climate during the exercise. Even if some of the items clearly pointed to collaboration, the dimension of collaboration was modest (i.e. 2.98 on a five-point Likert scale). A reason for this could be that relatively few considered the instructions clear on how to collaborate, and most of the participants found themselves repeating well-known activities during the exercise - so-called "drills" or procedural trainings. Berlin and Carlström (2015a) have deciphered between drills and collaborative exercises. A drill is defined as training of professional skills. In contrast, during a collaboration exercise the participant faces situations where he/she is forced to adapt their professional knowledge (from drills) to colleagues who have other professional skills (Scholtens, 2008).

The studied exercise was of an impressive size, and it was structured with multiple scenarios. In order to follow a rather strict schedule, a script for managing and controlling the exercise was outlined. The nine phases, from fire on-board a sea vessel to next of kin services, was relatively delimited from each other. This could have been one reason why more participants perceived repetitive drills vs collaboration that crossed professional and organisational boarders as characterising the exercise. In regard to learning, most of the participants did consider the exercise educative. The mean of all learning items was 3.22 on the five-point Likert scale. Overall, learning about collaborating organisations was sufficient, but a deeper knowledge (i.e. communication patterns and the use of concepts and abbreviations) was somewhat weaker.

Dependent: learning independent: collaborative characteristics of the exercise $R=0.86 ; R^{2}=0.74$; $R=0.79 ; F$-value $=8.48 ;$ Sig. $=0.00$

Biv. regr. Mult. regr. stand. $\beta \quad$ stand. $\beta \quad$ Difference $T$-value Sig.

1. The exercise focussed on collaboration

2. Discussions in connection to the exercise

3. Opportunities to improvise

0.41

0.39

\subsection{6}

$-0.05$

0.13

0.51

4. Collaboration was initiated immediately

5. Clear instructions of collaborative practice

0.36

0.22

0.30

$0.46 \quad 0.44$

0.44
0.26

0.26

0.29

0.06

0.02

0.32

$1.67 \quad 0.11$

6 . My points of view were regarded

0.58

$0.51 \quad 0.62$

$0.84 \quad 0.41$

$\begin{array}{ll}1.7 & 0.11\end{array}$

1.950 .06

Notes: $n=53$. Sig. $=p<0.05$
Dependent: usefulness independent: learning characteristics of the exercise $R=0.79 ; R^{2}=0.62$; $F$-value $=12.59 ;$ sig. $=0.00$

1. Learned new thing during the exercise

2. Learned about organisational aspects of the collaborating organisations

3. Learned about communication patterns of the collaborating organisations

Table V.

Multiple regression of items in the learning dimension of usefulness
4. Learned about the way collaborating organisations prioritise activities

5. Learned new concepts and abbreviations used by the collaborating organisations

Notes: $n=53$. Sig. $=p<0.05$

Biv. regr. Mult. regr.

stand $\beta \quad$ stand. $\beta \quad$ Difference $T$-value Sig.

$\begin{array}{lllll}0.63 & 0.61 & 0.02 & 4.36 & 0.00 \\ 0.50 & 0.20 & 0.30 & 1.11 & 0.27 \\ 0.50 & 0.14 & 0.36 & 0.70 & 0.49 \\ 0.42 & 0.02 & 0.40 & 0.16 & 0.87 \\ 0.45 & 0.22 & 0.23 & 1.86 & 0.07\end{array}$


One reason for this could be a lack of hotwash-up debriefs or seminars focussing on inter-agency collaboration after or more directly in connection to the exercise. Full-scale exercises the same size of the studied exercise is challenging when arranging "hot wash up" debriefings. There is a substantial risk that a debriefing will be superficial instead of digging deep into interorganisational differences affecting friction in collaboration efforts. When many participants from different organisations are gathered, few participants tend to ask questions and discussions become minimal. Cold debriefs held weeks or even months after an exercise can be useful in order to gain some distance from or perspective to the exercise, but when focussing on communicative differences a blurred memory can hinder a fruitful discussion (Paton et al., 1998).

Even if most of the participants regarded the exercise as useful, not more than 40 per cent considered it to have an impact on their daily work; one reason for this can be that the scenario was multifaceted and could be considered as non-realistic. On the other hand, the exercise was considered to test and develop collaboration between the participating organisations. Such inter-organisational collaboration is expected, no matter the scenario or the severity of a crisis, to be a daily practised tool in order to normalise the situation (Gjørv, 2012).

The regression showed a strong covariation between the collaboration dimension (86 per cent) and the learning dimension as well as the learning dimension and usefulness dimension (79 per cent). This underlines the connection between collaborative elements to learning and usefulness. If collaboration occurs (e.g. seminars in connection to the exercise), opportunities to improvise the exercise can be educative and useful in real-life crisis situations. On the contrary, an exercise lacking collaborative elements can have a weak influence on learning and usefulness. This underlines an important point for those who arrange and invest in exercises. In a study based on the same instrument, Berlin and Carlström (2015b) have shown an improved impact on collaboration as well as learning and usefulness during exercises especially tailored to increase the collaborative elements. The exercises were constructed with short repetitive elements and seminars in between aiming to improve collaboration. The exercises showed a mean collaboration of 3.97, 3.81 for learning, and 3.74 for usefulness on the CLU scale.

\section{Limitations}

We denote four limitations of this study: The effects of age, exercise experience, and gender were not investigated in this study. It could also be beneficial to address the issue of perceived collaboration by in-depth interviews among the participants. Furthermore, collaboration is highlighted as principal in the Norwegian context; this can provide a positive bias towards the collaboration concept at a symbolic level, addressing more the policy-levels rather than the practises (Goodlad, 1979). Even if collaboration is an emergency legislative principle in Norway, it needs more tailored practical exercises. The ideas of simplicity and complexity in training needs close attention. Furthermore, we recommend a more extensive focus on collaboration in exercises in order to create increased perceived learning and practical usefulness. This could lead the way to collaboration trainings and new learning practices.

This research is about perceived collaboration in a Norwegian context. A focus on social scientific methods provided by ethnography (Fetterman, 1998) is not included is this study. Such data could probably highlight more precisely the linkage between certain activities and perceived collaboration and learning.

\section{Conclusion}

Collaboration is one of four legislative principles of emergency work in Norway (Regjeringen, 2017). Therefore, a result $(M=4.2, \mathrm{SD}=0.99)$ from the exercise focus on collaboration is to be expected. Overall, the Exercise NORD 2016 displayed relatively sufficient figures when measuring collaboration. However, learning and usefulness has the potential to be improved, but also the analogy of the exercise phases as well.

Maritime crisis management exercise 
$\mathrm{DPM}$

27,1

Every phase contributed to a script-based exercise, possibly leaving out improvisation. Emergency training can improve learning and usefulness using collaborative training techniques where an intra-organisational focus is downplayed. Inter-organisational learning through common learning objectives might be beneficial. The problems with collaboration training (Van Wart and Kapucu, 2011; Andersson et al., 2014), where the training happens in parallel and more seldom synchronously, can with an increased focus on collaboration and inter-organisational activity can strengthen learning in this form of activities. Less complexity does not necessarily lead to naiveté; it might help participants discover dilemmas and insufficiencies in codes of conduct, rules, or practices. The option of running the same scenario twice can be useful to immediately test the ideas of improvement made in the first run.

\section{References}

Altman, D.G. (1991), Practical Statistics for Medical Research, Chapman and Hall, New York, NY.

Andersson, A., Carlstrøm, E., Ahgren, B. and Berlin, J.M. (2014), "Managing boundaries at the accident scene: a qualitative study of collaboration exercises", International Journal of Emergency Services, Vol. 3 No. 1, pp. 77-94.

Axelsson, R. and Bihari-Axelsson, S. (2006), "Integration and collaboration in public health: a conceptual framework", International Journal of Health Planning and Management, Vol. 21 No. 1, pp. $75-88$.

Berlin, J. and Carlström, E. (2008), "The 90-second collaboration: a critical study of collaboration exercises at extensive accident sites", Journal of Contingencies and Crisis Management, Vol. 16 No. 4, pp. 177-185.

Berlin, J. and Carlstrøm, E. (2009), "Samverkan på olycksplatsen: om organisatoriska barriäreffekter", [Collaboration on the accident site: About organisatoric barrier-effects], Universitatet i Väst, Trollhattan.

Berlin, J. and Carlström, E. (2011), "Why is collaboration minimised at the accident scene? A critical study of a hidden phenomenon”, Disaster Prevention and Management, Vol. 20 No. 2, pp. 159-171.

Berlin, J.M. and Carlström, E.D. (2013), "The dominance of mechanistic behaviour: A critical study of emergency exercises", International Journal of Emergency Management, Vol. 9 No. 4, pp. 327-350.

Berlin, J. and Carlström, E. (2015a), "Samverkansövningar: Om lärande och nytta (Collaboration excercises: Learning and Usefullnes)”, Bokförlaget BAS, Gøteborg.

Berlin, J. and Carlström, E. (2015b), "Learning and usefulness of collaboration exercises: a study of the three level collaboration (3LC) exercises between the police, ambulance, and rescue services", International Journal of Mass Emergencies and Disasters (IJMED), Vol. 33 No. 3, pp. $428-467$.

Bjørnstad, A. (2011), "Exploring network organization in military contexts: effects of flatter structure and more decentralized processes", Military Psychology (Taylor \& Francis Ltd), Vol. 23 No. 3, pp. 315-331, 17p, doi: 10.1080/08995605.2011.570595.

Carlson, E.J. (2014), "Collaboration and confrontation in interorganizational coordination: preparing to respond to disasters", dissertation, University of Illinois.

Dreyfus, H. and Dreyfus, St. (1986), Mind Over Machine, Free Press, New York, NY.

Fetterman, D.M. (1998), Ethnography: Step by Step, Vol. 2, SAGE publications, Thousand Oaks, CA.

Gjørv, A.B. (2012), Rapport fra 22. juli-kommisjonen (Report after 22. July): Oppnevnt ved kongelig resolusjon 12. August 2011 for å gjennomgå og trekke lærdom fra angrepene på regjeringskvartalet og Utøya 22. juli 2011: Avgitt til statsministeren 13. august 2012 (Vol. NOU 2012:14, Norges offentlige utredninger (tidsskrift: trykt utg.)), Departementenes servicesenter, Oslo. 
Goodlad, J. (1979), Curriculum Inquiry: The Study of Curriculum Practice, McGraw-Hill, New York, NY. Maritime crisis

Jamal, T.B. and Getz, D. (1995), “Collaboration theory and community tourism planning”, Annals of Tourism Research, Vol. 22 No. 1, pp. 186-204.

Joint Rescue Coordination Centers (2017), "Norwegian rescue services are carried out through cooperation between government agencies, voluntary organizations and private companies who have resources appropriate for rescue services", available at: www. hovedredningssentralen.no/english/

Kang, N. (2014), "Towards middle-range theory building in development research: Comparative (historical) institutional analysis of institutional transplantation", Progress in Development Studies, Vol. 14 No. 3, pp. 221-235, available at: http://doi:10.1177/1464993414521338

Kim, H. (2013), "Improving simulation exercises in Korea for disaster preparedness", Disaster Prevention and Management, Vol. 22 No. 1, pp. 38-47, doi: 10.1108/09653561311301961.

Kristiansen, E., Sorensen, J.L., Carlström, E. and Magnussen, L.I. (2017), "Time to rethink Norwegian maritime collaboration exercises", International Journal of Emergency Services, Vol. 6 No. 1, pp. 14-28.

Martinussen, B. (2013), "Internal security and preparedness in norway: analysis from different cultural perspectives [Norsk samfunnssikkerhet og beredskapsarbeid - analyser fra ulike kulturperspektiver]", Nordic Organization Studies, Vol. 3 No. 15, pp. 65-89.

Merton, R. (1949), Social Theory and Social Structure, Simon and Schuster, New York, NY.

Mills, C. (1959), The Sociological Imagination, Oxford University Press, New York, NY.

Murphy, M., Arenas, D. and Batista, J. (2015), "Value creation in cross-sector collaborations: the roles of experience and alignment”, Journal of Business Ethics, Vol. 130 No. 1, pp. 145-162, doi: 10.1007/ s10551-014-2204-x.

Nemeth, C., Wears, R., Patel, S., Rosen, G. and Cook, R. (2011), "Resilience is not control: Healthcare, crisis management, and ICT”, Cognition, Technology \& Work, Vol. 13 No. 3, pp. 189-202.

Paton, D., Johnston, D. and Houghton, B.F. (1998), “Organisational response to a volcanic eruption”, Disaster Prevention and Management, Vol. 7 No. 1, pp. 5-13.

Prytz, E.G., Rybing, J., Carlström, E., Khorram-Manesh, A. and Jonson, C.-O. (2015), "Exploring prehospital C2-work during a mass gathering event", International Journal of Emergency Services, Vol. 4 No. 2, pp. 227-241.

Regjeringen (Norwegian Government) (2017), "Hovedprinsipper i beredskapsarbeidet", Om regjeringens og departementenes beredskapsarbeid og krisehåndtering (Main principles in emergency work. About the Goverment and Ministeries emergency work), Policy statement, Oslo, available at: www.regjeringen.no/no/tema/samfunnssikkerhet-og-beredskap/innsikt/ hovedprinsipper-i-beredskapsarbeidet/id2339996/ (accessed 30 September 2017).

Scholtens, A. (2008), "Controlled collaboration in disaster and crisis management in the Netherlands: history and practice of an overestimated and underestimated concept", Journal of Contingency and Management, Vol. 16 No. 4, pp. 195-207.

Steiro, T. and Torgersen, G.E. (2013), "The terms of interaction and concurrent learning in the definition of integrated operations", in Hepsø, I. and Hepsø, V. (Eds), Integrated Operations in the Oil and Gas Industry: Sustainability and Capability Development, IGI Global, Trondheim, pp. 328-340.

Torgersen, G.E. (Ed.) (2015), Pedagogikk for det Uforutsette [Pedagogy for the Unforeseen], Fagbokforlaget, Bergen.

Torgersen, G.E. and Steiro, T. (2009), "Ledelse, samhandling og opplæring i fleksible organisasjoner [leadership, collaboration and training in flexible firms]", Læringsforlaget, Stjørdal.

Van Wart, M. and Kapucu, N. (2011), "Crisis management competencies”, Public Management Review, Vol. 13 No. 4, pp. 489-511. 


\section{Further reading}

Boin, A., 'tHart, P., Stern, E. and Sundelius, B. (2006), The Politics of Crisis Management: Public Leadership Under Pressure, Cambridge University Press, Cambridge.

Carlström, E. and Berlin, J. (2009), "Var och en på sin kant. -Om avsaknaden av synkron samverkan på olycksplatsen, [Everyone on their own side: the lack of collaboration on the accident scene]", Kommunal Ekonomi Och Politik, Vol. 13 No. 3, p. 7.

Hovedredningssentralen [Norwegian Joint Rescue Coordination Centres] (2016), "Ansvarsområde (Areas of responsibility)", available at: www.hovedredningssentralen.no/norsk-redningstjeneste/ (accessed 20 October 2017).

\section{Corresponding author}

Leif Inge Magnussen can be contacted at:1ma@usn.no

For instructions on how to order reprints of this article, please visit our website: 